\title{
Vitamin D in Autistic Children and Healthy Controls
}

\author{
M. BIČÍKOVÁ ${ }^{1}$, L. MÁČOVÁ ${ }^{1}$, D. OSTATNÍKOVÁ ${ }^{2}$, L. HANZLÍKOVÁ \\ ${ }^{1}$ Institute of Endocrinology, Prague, Czech Republic, ${ }^{2}$ Institute of Physiology, Faculty of Medicine, \\ Bratislava, Slovak Republic, ${ }^{3}$ The National Institute of Public Health, Prague, Czech Republic
}

Received March 6, 2018

Accepted September 25, 2018

Epub Ahead of Print January 10, 2019

\begin{abstract}
Summary
Insufficient levels of vitamin $D$ have been demonstrated by many authors as a risk factor for autistic patients, however, the causality has not been reliably elucidated. In the present study, levels of calcidiol were determined in group of autistic children and compared with age matched healthy children as controls. Suboptimal levels of calcidiol in more than $60 \%$ of both autistic patients as well as of control group were found. No significant differences in vitamin $D$ between autistic children and healthy controls were observed.
\end{abstract}

\section{Key words}

Vitamin D • Children • Calcidiol • Calcitriol • Autism

\section{Corresponding author}

L. Máčová, Institute of Endocrinology, Národní 8, 11694 Prague, Czech Republic. Email: Imacova@endo.cz

For many years it was thought that the only role of calcitriol is the regulation of calcium kinetics, but in the past 15 years there have been an increasing number of studies suggesting varied actions of vitamin D (Basit 2013). Fifteen years ago it was also suggested that vitamin D was the "forgotten neurosteroid" (McGrath et al. 2001). Hence, there is a handful of evidence that vitamin D plays an important role in the brain and nervous system health and disease (DeLuca et al. 2013, Ramakrishna 1999). Low pre- and perinatal saturation with vitamin D may be a candidate risk factor for the later development of multiple disease including multiple sclerosis (MS), depression, seasonal affective disorders, schizophrenia, Alzheimer's disease (AD), Parkinson's disease (Eyles et al. 2013, Littlejohns et al. 2014) and others. Among the mental disorders stands out child autism (autism spectrum disorder, ASD) characterized by deficits in social communication, and which incidence has constantly risen in recent years. Typical manifestation of the disease is the repetitive and restricted patterns of behavior (Wang et al. 2016). According to many authors, there is a danger of ASD in children with low vitamin D level at birth. Literature about this problem was summarized elsewhere (Macova et al. 2017), but the number of publications is constantly rising (Cannell 2017b, Wu et al. 2017). Depressive symptoms as irritability and agitation are possibly observed as an autism comorbidity (Ghaziuddin 2005, Stewart et al. 2006) and other depressive symptoms can complicate ASD diagnosis. There are many reports describing that low levels of vitamin D or calcidiol are associated with major depression (Jozefowicz et al. 2014) or symptoms of depression (Black et al. 2014, Kerr et al. 2015, Maddock et al. 2013, Milaneschi et al. 2014), but no effect on reducing the severity of these symptoms was found with vitamin D supplementation (Gowda et al. 2015, Kjaergaard et al. 2012). Current evidences have not yet definitively demonstrated if vitamin D deficiency is a cause or risk factor for developing depression or if vitamin $\mathrm{D}$ is an effective therapy for depression (Howland 2011).

In contrast to the reports on vitamin D association with depression, fewer contributions have been published on the association of anxiety disorders with the levels of vitamin D (Armstrong et al. 2007). Some of them even deny the relation of vitamin D 
deficiency with anxiety or stress (Black et al. 2014).

General term Vitamin D primarily means Vitamin D3 (cholecalciferol) produced after exposure to UVB radiation by skin from 7-dehydrocholesterol and taken in limited amounts from diet. Vitamin D2 (ergocalciferol) is of plant origin. Both vitamins are inactive and transported to the liver bounded to vitamin $\mathrm{D}$ binding protein, where they are metabolized to respective 25-hydroxyvitamin D metabolite called calcidiol.

Calcidiol is a stable form of vitamin D with the biological half-life 6-8 weeks and in this form it is also stored in the body. Therefore, its level measured in blood reflects the real saturation of organism by vitamin D. Calcidiol is biologically inactive until conversion to 1,25-dihydroxymetabolite (mainly in proximal tubule of kidneys) called calcitriol, which is biologically active form but remains stable only for several minutes.

In our study, calcidiol levels were investigated in 45 boys, 4-7 of age, suffering from ASD and compared with the levels of calcidiol in a group of 40 age matched healthy boys as controls. A commercially available ECLIA method (Roche, Switzerland) was used to determine vitamin D levels. All children were divided into groups according to season of blood collection to avoid the effect of calcidiol fluctuations throughout the year. However, the differences between each groups were not statistically significant (Fig. 1 and Table 1).

At the end of 2016, the study of National Institute of Public Health of Czech Republic on 419 healthy children (boys and girls) was finished. Participants were children between 5 and 9 years of age. Levels of vitamin D were measured during the whole year 2016 by the same method as mentioned above. The results were very similar as found in our study with autistic children (Hanzlíková et al. 2018).

Table 1. Vitamin $D$ in autistic (ASD) and control group (in $\mathrm{nmol} / \mathrm{l})$.

\begin{tabular}{lcc}
\hline & control group & ASD \\
\hline Number of subjects & 40 & 45 \\
Average vitD & 70.348 & 65.066 \\
Median vitD & 64.46 & 65.22 \\
Standard deviation & 20.733 & 25.950 \\
Min vitD & 26.71 & 22.03 \\
Max vitD & 128.2 & 136.1 \\
Lower quartile & 57.495 & 44.47 \\
Upper quartile & 82.8 & 83.5 \\
\hline
\end{tabular}

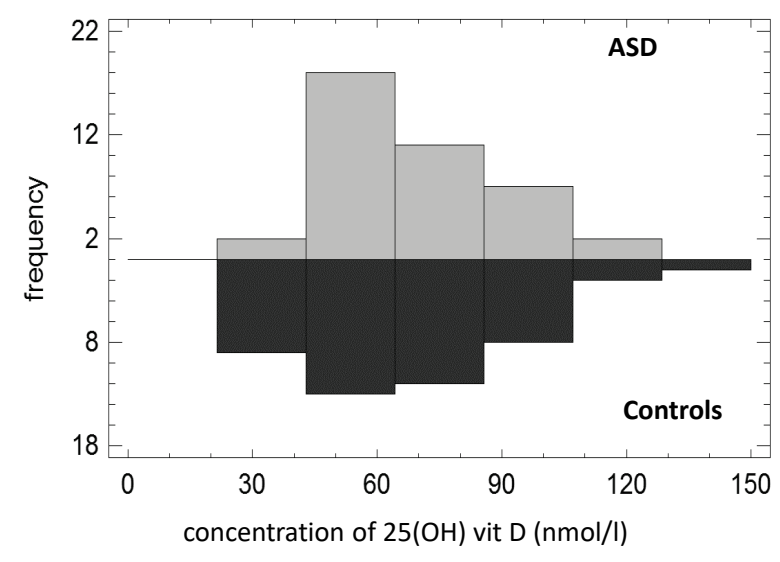

Fig. 1. Distribution of ASD patients/controls in groups according to vitamin D level.

In Czech and Slovak Republics, the recommended blood levels of calcidiol are at least $75 \mathrm{nmol} / \mathrm{l}$. This is in agreement with the USA Vitamin D Council (30-100 ng/ml corresponding to $75-250 \mathrm{nmol} / \mathrm{l}$ ) as well as the Endocrine Society in the USA which made recommendations to treat and prevent vitamin D deficiency by achieving serum $25(\mathrm{OH}) \mathrm{D}$ concentrations of more than $30 \mathrm{ng} / \mathrm{ml}(>75 \mathrm{nmol} / 1)$, with the preferred range of $40-60 \mathrm{ng} / \mathrm{ml}(100-150 \mathrm{nmol} / \mathrm{l})$ (Holick et al. 2011, Weydert 2014). Vitamin D toxicity has never been reported, in adults or children, with $25(\mathrm{OH}) \mathrm{D}$ levels below $200 \mathrm{ng} / \mathrm{ml}$ (500 nmol/l) (Cannell 2017a, Pludowski et al. 2018).

There is a handful of studies dealing with the relationship of vitamin D and the development of the nervous system in Czech children. The recent study analyzed associations between vitamin $\mathrm{D}$ and the parameters of bone metabolism (including vitamin $\mathrm{D}$ ) and muscle development in adolescent girls (Cirmanova et al. 2017).

In our opinion, it is crucial to use a more sensitive method for measuring actual vitamin D levels, as commonly used methods do not distinguish between calcidiol and mixture of metabolic products, what results in high percentage of cross-reactions. The correct answer could be given by the chromatographic method in future. Our team is currently developing a novel chromatographic method that separates and accurately determinates vitamin $\mathrm{D}$ metabolites.

Surprisingly, we did not observe statistically significant differences in vitamin $\mathrm{D}$ between autistic children and healthy controls. Our results suggest poor supply of young population with vitamin D. We found suboptimal levels of vitamin D in more than $60 \%$ of both 
autistic patients as well as of control groups. Our observation raised a question about the adequate vitamin D level needed for the physiologic development in juvenile population. Studies confirm that long-term vitamin $\mathrm{D}$ insufficiency leads to manifestation of neurodevelopmental disorders such as depression, anxiety, RS, AD and negative influence on immunometabolism (Vanherwegen et al. 2017).

In summer, healthy children do not need supplementation by vitamin D if they are exposed long enough to the sun. In winter, it is necessary to check the level of vitamin D (calcidiol) at least $75 \mathrm{nmol} / \mathrm{l}$ is desired. Once the level is lower, it is necessary to initiate or increase usage of nutritional supplements with readily absorbable vitamin D and to increase the consumption of fish to activate the neuroimmune system and balance the body homeostasis.

In pregnant and breastfeeding women, especially during October-April, replenishment is necessary! The international consensus recommends a flat-rate supplemental dose of 500-600 IU per day, with infants still supplying $1000 \mathrm{mg}$ of calcium daily (Munns et al. 2016).

It is not possible to overdose vitamin D (= cholecalciferol) at the dose determined by the physician and if it is not for patients with sarcoidosis, granulomatous diseases or hypercalcemia!

\section{Conflict of Interest}

There is no conflict of interest.

\section{Acknowledgements}

The study was supported by MH CZ - DRO (Institute of Endocrinology - EÚ, 00023761), by grants APVV-150045 and APVV-15-0085.

\section{References}

ARMSTRONG DJ, MEENAGH GK, BICKLE I, LEE AS, CURRAN ES, FINCH MB: Vitamin D deficiency is associated with anxiety and depression in fibromyalgia. Clin Rheumatol 26: 551-554, 2007.

BASIT S: Vitamin D in health and disease: a literature review. Br J Biomed Sci 70: 161-172, 2013.

BLACK LJ, JACOBY P, ALLEN KL, TRAPP GS, HART PH, BYRNE SM, MORI TA, BEILIN LJ, ODDY WH: Low vitamin D levels are associated with symptoms of depression in young adult males. Aust $N Z J$ Psychiatry 48 : 464-471, 2014.

CANNELL JJ: How safe is vitamin D? https://www.vitamindcouncil.org/how-safe-is-vitamin-d/, 2017a.

CANNELL JJ: Vitamin D and autism, what's new? Rev Endocr Metab Disord 18: 183-193, 2017b.

CIRMANOVA V, ZOFKOVA I, KASALICKY P, LANSKA V, BAYER M, STARKA L, KANCEVA R: Hormonal and bone parameters in pubertal girls. Physiol Res 66: S419-S424, 2017.

DELUCA GC, KIMBALL SM, KOLASINSKI J, RAMAGOPALAN SV, EBERS GC: Review: the role of vitamin D in nervous system health and disease. Neuropathol Appl Neurobiol 39: 458-484, 2013.

EYLES DW, BURNE TH, MCGRATH JJ: Vitamin D, effects on brain development, adult brain function and the links between low levels of vitamin D and neuropsychiatric disease. Front Neuroendocrinol 34: 47-64, 2013.

GHAZIUDDIN M: Mental Health Aspects of Autism and Asperger Syndrome. JESSICA KINGSLEY PUBLISHERS, London, 2005.

GOWDA U, MUTOWO MP, SMITH BJ, WLUKA AE, RENZAHO AM: Vitamin D supplementation to reduce depression in adults: meta-analysis of randomized controlled trials. Nutrition 31: 421-429, 2015.

HANZLÍKOVÁ L, SOCHOROVÁ L, PUKLOVÁ V, ČERNÁ M, FIALOVÁ AC, VOSÁTKOVÁ M, BIČÍKOVÁ M, KUBÍNOVÁ R: Jsou české děti dostatečně zásobeny vitaminem D? (in Czch) Vox Pediatriae 18: 34-35, 2018.

HOLICK MF, BINKLEY NC, BISCHOFF-FERRARI HA, GORDON CM, HANLEY DA, HEANEY RP, MURAD MH, WEAVER CM: Evaluation, treatment, and prevention of vitamin D deficiency: An Endocrine Society clinical practice guideline. J Clin Endocrinol Metab 96: 1911-1930, 2011.

HOWLAND RH: Vitamin D and depression. J Psychosoc Nurs Ment Health Serv 49: 15-18, 2011.

JOZEFOWICZ O, RABE-JABLONSKA J, WOZNIACKA A, STRZELECKI D: Analysis of vitamin D status in major depression. J Psychiatr Pract 20: 329-337, 2014.

KERR DC, ZAVA DT, PIPER WT, SATURN SR, FREI B, GOMBART AF: Associations between vitamin D levels and depressive symptoms in healthy young adult women. Psychiatry Res 227: 46-51, 2015. 
KJAERGAARD M, EGGEN AE, MATHIESEN EB, JORDE R: Association between headache and serum 25-hydroxyvitamin D: the Tromso Study: Tromso 6. Headache 52: 1499-1505, 2012.

LITTLEJOHNS TJ, HENLEY WE, LANG IA, ANNWEILER C, BEAUCHET O, CHAVES PH, FRIED L, KESTENBAUM BR, KULLER LH, LANGA KM, LOPEZ OL, KOS K, SONI M, LLEWELLYN DJ: Vitamin D and the risk of dementia and Alzheimer disease. Neurology 83: 920-928, 2014.

MACOVA L, BICIKOVA M, OSTATNIKOVA D, HILL M, STARKA L: Vitamin D, neurosteroids and autism. Physiol Res 66: S333-S340, 2017.

MADDOCK J, BERRY DJ, GEOFFROY MC, POWER C, HYPPONEN E: Vitamin D and common mental disorders in mid-life: cross-sectional and prospective findings. Clin Nutr 32: 758-764, 2013.

MCGRATH J, FERON F, EYLES D, MACKAY-SIM A: Vitamin D: the neglected neurosteroid? Trends Neurosci 24: 570-572, 2001.

MILANESCHI Y, HOOGENDIJK W, LIPS P, HEIJBOER AC, SCHOEVERS R, VAN HEMERT AM, BEEKMAN AT, SMIT JH, PENNINX BW: The association between low vitamin D and depressive disorders. Mol Psychiatry 19: 444-451, 2014.

MUNNS CF, SHAW N, KIELY M, SPECKER BL, THACHER TD, OZONO K, MICHIGAMI T, TIOSANO D, MUGHAL MZ, MAKITIE O, RAMOS-ABAD L, WARD L, DIMEGLIO LA, ATAPATTU N, CASSINELLI H, BRAEGGER C, PETTIFOR JM, SETH A, IDRIS HW, BHATIA V, FU J, GOLDBERG G, SAVENDAHL L, KHADGAWAT R, PLUDOWSKI P, MADDOCK J, HYPPONEN E, ODUWOLE A, FREW E, AGUIAR M, TULCHINSKY T, BUTLER G, HOGLER W: Global Consensus Recommendations on Prevention and Management of Nutritional Rickets. J Clin Endocrinol Metab 101: 394-415, 2016.

PLUDOWSKI P, HOLICK MF, GRANT WB, KONSTANTYNOWICZ J, MASCARENHAS MR, HAQ A, POVOROZNYUK V, BALATSKA N, BARBOSA AP, KARONOVA T, RUDENKA E, MISIOROWSKI W, ZAKHAROVA I, RUDENKA A, LUKASZKIEWICZ J, MARCINOWSKA-SUCHOWIERSKA E, LASZCZ N, ABRAMOWICZ P, BHATTOA HP, WIMALAWANSA SJ: Vitamin D supplementation guidelines. J Steroid Biochem Mol Biol 175: 125-135, 2018.

RAMAKRISHNA T: Vitamins and brain development. Physiol Res 48: 175-187, 1999.

STEWART ME, BARNARD L, PEARSON J, HASAN R, O'BRIEN G: Presentation of depression in autism and Asperger syndrome: a review. Autism 10: 103-116, 2006.

VANHERWEGEN AS, GYSEMANS C, MATHIEU C: Vitamin D endocrinology on the cross-road between immunity and metabolism. Mol Cell Endocrinol 453: 52-67, 2017.

WANG T, SHAN L, DU L, FENG J, XU Z, STAAL WG, JIA F: Serum concentration of 25-hydroxyvitamin D in autism spectrum disorder: a systematic review and meta-analysis. Eur Child Adolesc Psychiatry 25: 341-350, 2016.

WEYDERT JA: Vitamin D in Children's Health. Children (Basel) 1: 208-226, 2014.

WU DM, WEN X, HAN XR, WANG S, WANG YJ, SHEN M, FAN SH, ZHUANG J, LI MQ, HU B, SUN CH, BAO YX, YAN J, LU J, ZHENG YL: Relationship Between Neonatal Vitamin D at Birth and Risk of Autism Spectrum Disorders: the NBSIB Study. J Bone Miner Res 33: 458-466 2018. 